\title{
PENGEMBANGAN KAWASAN INDUSTRI DALAM MEMAKSIMALKAN PENDAPATAN ASLI DAERAH (PAD) DI KOTA SEMARANG SUATU PERSPEKTIF KONSEP PEMBANGUNAN BERKELANJUTAN
}

\author{
Muhammad Junaidi, SHI, MH
}

\begin{abstract}
Abstrak
Di Kota Semarang terdapat 9 (sembilan) kawasan Industri tersebut adalah kawasan industri Wijayakusuma, Kawasan Industri Terboyo, Kawasan Industri Lamicitra Nusantara, dan Kawasan Industri Bukit Semarang Baru, Lingkungan industri Kecil Bugangan Baru, Kawasan Industri Guna Mekar Tambak Aji, Kawasan Industri Candi, Kawasan Industri Tugu, dan Kawasan Industri Sinar Centra Cipta. Tingkat okupansi sembilan kawasan industri seluas 1.029 hektare di kota itu mencapai 75\%. Namun pada sisi lain persoalan yang kemudian mengemuka adalah masalah lingkungan hidup.

Materi dan muatan yang terkandung dalam Peraturan Pemerintah No 24 Tahun 2009 tentang Kawasan Industri yang kemudian dijabarkan dalam Peraturan Daerah Pemerintah Kota Semarang No 14 tahun 2011 tentang Rencana Tata dan Ruang Wilayah telah baik. Namun yang perlu diperhatikan adalah bagaimana kemampuan pemerintah daerah saat ini untuk menjabarkan kebijakan tersebut di lapangan. Indicator adanya ketidak konsistenan tersebut adalah terdapat pembiaran atas pembuangan limbah pada beberapa lokasi kawasan industri.

Selayaknya dengan pengembangan kawasan industri, pemerintah secara sadar menjadi dipermudah dalam melakukan pengontrolan apabila terjadinya penyimpangan. Namun jika pemerintah tidak serius dan hanya berorientasi keuntungan semata, maka akan dikhawatirkan menimbulkan problematika di kemudian hari yaitu persoalan dilema dan ketimpangan pembangunan yang utamanya diharapkan dapat dijalankan pada masa yang akan datang.
\end{abstract}

Kata kunci : kawasan industri, PAD dan pembangunan berkelanjutan

\begin{abstract}
in Semarang there are nine (9) The industrial area is an industrial area Wijayakusuma, Terboyo Industrial Area, Industrial Area Lamicitra archipelago, and New Semarang Hill Industrial Estate, Small industries Bugangan New Environmental, Industrial Area To Bloom Pond Aji, Region Temple industry, Industrial Area Monument, and Sinar industrial Estate Centra reserved. The occupancy rate of nine industrial area covering 1,029 hectares in the city reached $75 \%$. But on the other hand is the issue then raised environmental concerns.

The material and content contained in Government Regulation No. 24 of 2009 on the Industrial Estate which is then translated in Semarang City Government Regional Regulation No. 14 of 2011 on Regional Spatial Layout Plan and have good. But keep in mind is how the local government's ability to describe the current policy on the ground. Indicator some inconsistency is there nullifying the disposal of waste at several locations industrial area.

Should the development of industrial estates, the government consciously become easy in controlling when the deviation. But if the government is not serious and just a profit-oriented, it will concern the problems in the future raises the question of the dilemma and the main development gaps which are expected to run in the future.
\end{abstract}

Keywords : industrial area, PAD and sustainable development 


\section{PENDAHULUAN}

Dibandingkan dengan daerah lain Jumlah Perusahaan Dan Jumlah Tenaga Kerja Di Jawa Tengah, Kota Semarang lebih mendominasi di bandingkan dengan kabupaten atau Kota lain di Jawa Tengah. Tentunya hal ini juga berkaitan erat dari model kebijakan yang diambil oleh pemerintah Kota Semarang dalam melakukan pembuatan kebijakan yang secara sah melegitimasi adanya keinginan pengagalian potensi daerah yang ada di Kota Semarang.

Dipihak lain, dengan jumlah industri yang berkembang cukup dominan tersebut menjadi problem tersendiri. Diantara masalah tersebut adalah kaitannya terhadap pengelolaan lingkungan yang dilakukan oleh industri yang berkembang di Kota Semarang. Berdasarkan pengamatan secara langsung oleh peneliti di Kota Semarang tepatnya di kawasan industri BSB City, Mijen Kota Semarang, terdapat beberapa lokasi pabrik yang dibangun sebagai bagian dari wujud pengembangan kawasan industri di Kota Semarang yang tidak mengindahkan pengelolaan lingkungan dengan baik yang dalam praktiknya dengan membuang limbang secara sembarangan.

Hasil pengamatan langsung peneliti di lapangan ini nampaknya dibenarkan oleh sebuah hasil penelitian yang menunjukkan bahwa pencemaran pada kawasan industri BSB City, Mijen Kota Semarang yang diperolah tahun 2012 yang didapat dengan uji laboratorium dengan pengambilan sampel di lima titik pencemar pada saluran drainase menunjukkan pencemaran pada parameter utama TSS (Total Suspended Solids) 1130,2 mg/ 1, BOD (Biological Oxygen Demand) 180,27 mg/l, COD (Chemical Oxygen Demand) 392,23 mg/l. sedangkan pada Peraturan Menteri Lingkungan Hidup No. 3 Tahun 2010 baku mutu parameter yang diperlukan effluent menuju badan air yaitu TSS 150 $\mathrm{mg} / \mathrm{l}$, BOD $50 \mathrm{mg} / \mathrm{l}$, COD $100 \mathrm{mg} / \mathrm{l}$. Nilai TSS, BOD, COD pada laboratorium tentunya diatas ambang bak mutu air limbah kawasan industri, maka dari itu dibutuhkan pengolahan terlebih dahulu ${ }^{1}$.

Mencermati adanya kondisi yang demikian tentunya perlu dilakukan respon secara cepat terkait bagaimana tindakan yang seharusnya dilakukan pada nantinya agar kebijakan-kebijakan yang secara strategis diambil oleh pemerintah daerah Kota Semarang bukan hanya mengambil keuntungan melalui peningkatan Pendapatan Asli Daerah, akan tetapi juga memaksimalkan pembangunan pada masa yang akan datang.

Melihat kondisi yang demikian di kota semarang penulis tertarik untuk mengangkat tema penelitian tersebut dengan beberapa masalah sebagai : a. Bagaimana implementasi pengembangan kawasan industri dalam memaksimalkan Pendapatan Asli Daerah (PAD) Di Kota Semarang? b. Bagaimana perspektif konsep pembangunan berkelanjutan terhadap implementasi pengembangan kawasan industri dalam memaksimalkan Pendapatan Asli Daerah (PAD) Di Kota Semarang?.

Manfaat yang dalam penelitian ini: a. diharapkan hasil penelitian nantinya dapat menjadi acuan pemerintah daerah utamanya pemerintah daerah Kota Semarang dalam melakukan

\footnotetext{
1 Fazalaili Rahmawati A Dkk, Detail Engineering desain (ded) sistem Penyaluran air limbah dan instalasi pengolahan Air limbah kawasan industri bsb city, mijen Kota Semarang, diunduh dari situs yang beralamat di eprints.undip.ac.id/40954/1/JURNAL.docx
} 
evaluasi kebijakan terkait pengembangan kawasan industri yang berbasis Pendapatan Asli Daerah (PAD), b. Diharapkan hasil penelitian nantinya dapat menjadi sarana untuk memunculkan ide-ide baru terkait pelaksanaan pengembangan kawasan industri berbasis Pendapatan Asli Daerah (PAD) yang lebih menonjolkan kepentingan masa depan umat manusia utamanya pada masa yang akan dating dan, c. Diharapkan hasil penelitian nantinya mampu menjadi bahan pertimbangan pengambilan kebijakan pembangunan kawasan industri berbasis Pendapatan Asli Daerah (PAD) di seluruh Indonesia utamanya terlebih di Kota Semarang.

\section{METODE PENELITIAN}

Metode pendektan yang digunakan adalah Pendekatan yuridis normatif. Pendekatan yuridis normatif yaitu pendekatan yang menggunakan konsep legis positivis yang menyatakan bahwa hukum adalah identik dengan norma-norma tertulis yang dibuat dan diundangkan oleh lembaga-lembaga atau pejabat yang berwenang. Selain itu konsep ini juga memandang hukum sebagai sistem normatif yang bersifat otonom, tertutup dan terlepas dari kehidupan masyarakat. $^{2}$

Spesifikasi penelitian yang digunakan dalam penelitian ini adalah diskriptif analitis, penggunaan diskriptif diharapkan dapat memberikan gambaran secara umum dan menyeluruh tentang obyek yang diteliti, suatu penelitian diskriptif dimaksudkan untuk memberikan data yang seteliti mungkin tentang

\footnotetext{
2 Ronny Hanitijo Soemitro, 1988, Metode Penelitian Hukum dan jurimetri, Ghalia Indonesia, Jakarta, hlm. 11.
}

manusia, keadaan dan gejala-gejala lainnya. $^{3}$

Jenis data dalam penelitian ini adalah data sekunder. Data sekunder berupa dari bahan hukum primer, bahan hukum sekunder dan bahan hukum tersier. Baik bahan hukum primer, bahan hukum sekunder dan bahan hukum tersier dapat ditemukan diantaranya melalui studi kepustakaan.

Metode analisis yang digunakan adalah dengan analisis data secara kualitatif. Dalam menjalankan proses analisis data kualitatif prosesnya dijalankan sebagai berikut ;

a. Mencatat yang menghasilkan catatan lapangan, dengan hal itu diberi kode agar sumber datanya tetap ditelusuri.

b. Mengumpulkan, memilah, mengklasifikasikan, mensintesiskan, membuat ikhtisar dan membuat indeksnya.

c. Berpikir, dengan jalan membuat agar kategori data itu mempunyai makna, mencari dan menemukan pola dan hubungan-hubungan, dan temuantemuan umum ${ }^{4}$.

\section{HASIL DAN PEMBAHASAN}

Salah satu bentuk dari hadirnya Negara dalam sebuah aktivitas mewujudkan Negara kesejahteraan adalah lahirnya industrialisasi. Idustrialisasi yang berkembang di Indonesia telah menggambarkan lahirnya gagasangagasan Karl Mark tentang industrialisasi sebagai penopang kemajuan peradaban manusia. Tidak bisa dipungkiri Madzhab industrialisasi bukan menjadi sebuah referensi Negara sosialis saja,

\footnotetext{
${ }^{3}$ Soerjono Soekanto, 1981, Pengantar Penelitian Hukum, UI Press, Jakarta, hlm 10

${ }^{4}$ Lexi J. Moleong, 2007, Metodologi Penelitian Kualitatif, Rosda, Bandung, hlm. 248.
} 
akan tetapi juga Negara bermadzhab demokratis bahkan liberal.

Di Indonesia sendiri, dampak dari pemikiran sosialis telah melahirkan dan atau terbentuknya kawasan-kawasan industri di kabupaten/kota maupun provinsi di seluruh Indonesia. Nilai positif tentunya adanya pengembangan kawasan industri tersebut telah membuat terserapnya lapangan pekerjaan. Lapangan pekerjaan yang mudah sangat berdampak penting bagi Negara Indonesia yang memiliki tingkat kepadatan penduduk yang sangat tinggi.

Indonesia saat ini menjadi Negara yang mengalami situasi gawat darurat masalah pengangguran. Sepanjang bulan Februari hingga Agustus 2014, jumlah pengangguran di Indonesia bertambah 0,09 juta orang dari 7,15 juta orang meningkat 7,24 juta orang. Dengan jumlah ini, tingkat ini diprediksi akan bertambah karena pertumbuhan ekonomi yang melambat di 5,01\%. Menurut Badan Pusat Statistik (BPS), jumlah angkatan kerja di Indonesia mencapai 121,87 juta orang, yang meningkat dari Agustus tahun 2013 sebesar 120,17 juta orang. Tetapi peningkatan ini juga terjadi pada tingkat pengangguran terbuka Februari hingga Agustus 2014 sebesar 5,70\% naik $5,94 \% \%^{5}$.

Di Kota Semarang, angka pengangguran sangat minim dibandingkan daerah-daerah lain di Jawa Tengah. Hal tersebut seperti terungkap dalam data jumlah tenaga kerja di Kota Semarang 276.613. Secara tidak langsung hal ini dapat disimpulkan bahwa lapangan pekerjaan yang dalam kategori ini adalah

\footnotetext{
${ }^{5}$ Kontan.co.id, 7,24 juta orang Indonesia adalah pengangguran, diunduh pada tanggal 12 januari 2015 pada situs http://nasional.kontan.co.id/news/724-juta-orangindonesia-adalah-pengangguran
}

bagian dari masalah sosial sedikit banyak telah diatasi dengan jumlah perusahaan.

Persoalan lain kemudian adalah dengan semakin banyaknya jumlah perusahaan di samping menimbulkan dampak positif yang sangat menguntungkan masyarakat utamanya pada sektor terserapnya lapangan pekerjaan, juga menimbulkan dampak negatif. Diantara dampak negatifnya adalah masalah lingkungan.

Industrialisasi Kota Semarang Jawa Tengah merujuk data yang dilansir dari data Disperindag Kota Semarang menyebutkan jumlah total industri kecil, sedang dan besar di Kota Semarang pada 2013 sebanyak 3.325. Dari jumlah tersebut, sekitar 2.000-an berkategori industri sedang dan besar dengan nilai investasi di atas Rp200 juta.

Jumlah industri kecil, sedang dan besar di Kota Semarang yang signifikan tersebut telah memberikan sebuah indikator adanya kemajuan dalam praktik industrialisasi di Kota Semarang. Di Kota Semarang kawasan industri berjumlah 9 (sembilan). 9 (sembilan) kawasan Industri tersebut adalah:

1. kawasan industri Wijayakusuma;

2. Kawasan Industri Terboyo;

3. Kawasan Industri Lamicitra Nusantara;

4. Kawasan Industri Bukit Semarang Baru;

5. Lingkungan industri Kecil Bugangan Baru;

6. Kawasan Industri Guna Mekar Tambak Aji;

7. Kawasan Industri Candi;

8. Kawasan Industri Tugu, dan;

9. Kawasan Industri Sinar Centra Cipta.

Dinas Perindustrian dan Perdagangan Kota Semarang mengungkapkan tingkat okupansi sembilan kawasan industri seluas 1.029 hektare di 
kota itu mencapai 75\%. Nurjanah, Kepala Disperindag Kota Semarang, menuturkan saat ini ada sembilan kawasan industri di wilayah Kota Semarang, yakni Kawasan Industri Wijayakusuma, Kawasan Industri Terboyo, Kawasan Industri Lamicitra Nusantara, dan Kawasan Industri Bukit Semarang Baru. Selain itu, Lingkungan industri Kecil Bugangan Baru, Kawasan Industri Guna Mekar Tambak Aji, Kawasan Industri Candi, Kawasan Industri Tugu, dan Kawasan Industri Sinar Centra Cipta. "Total arealnya sekitar 1.027 ha. Okupansinya rata-rata sudah di atas $75 \%$, bahkan ada yang sudah penuh, kecuali Kawasan Industri BSB karena itu kan masih baru," ujarnya, Kamis (8/5/2014). Kawasan industri BSB, tuturnya, merupakan kawasan industri seluas total 112 ha yang dikhususkan untuk industri nonpolutan, seperti industri perakitan elektronik dan kendaraan bermotor, serta industri garmen ${ }^{6}$.

Melalui jumlah kawasan industri yang demikian, telah memberi pengaruh yang besar terhadap Pendapatan Asli Daerah (PAD). Pada tahun 2012, Kota Semarang memiliki PAD mencapai Rp 2,421 triliun. Jumlah itu mengalami peningkatan dibanding tahun sebelumnya $\mathrm{Rp} 2,203$ triliun. Hal tersebut disampaikan Plt Wali Kota Semarang, Hendrar Prihadi usai menyerahkan Dokumen Pelaksanaan Anggaran (DPA) SKPD Tahun Anggaran 2013 dan penandatanganan Pakta Integritas di Gedung Moch Ikhsan lantai 8, Kompleks Balai Kota, Senin (14/1). Data yang dihimpun dari DPKAD, pendapatan daerah peningkatan pendapatan daerah

6

http://kabar24.bisnis.com/read/20140508/78/226 142/kawasan-industri-kota-Semarang-hampirpenuh ini bersumber dari peningkatan PAD (Pendapatan Asli Daerah), dari Rp 660,372 miliar menjadi Rp 714,026 miliar, dana perimbangan dari Rp 1,106 triliun menjadi Rp 1,201 triliun? ${ }^{7}$.

Jumlah pendapatan asli daerah yang cukup fantastis naik tersebut di atas ternyata menjadi semangat pada sisi lain untuk memaksimalkan mengembangkan kawasan industri. Namun, semangat yang dimiliki pemerintah daerah tersebut nampaknya harus dihadapkan pada aturan-aturan yang salah satunya Peraturan Daerah Pemerintah Kota Semarang No 14 tahun 2011 tentang Rencana Tata dan Ruang Wilayah.

Namun persoalan lain adalah dengan adanya ketidak aturan dari segi penegakan hokum dalam pengelolaan industrialisasi memungkinkan akibat buruk yaitu pengelolaan lingkungan yang kurang bermutu/baku mutu lingkungan dan masalah sosial seperti adanya gesekan antara masyarakat dengan pabrik yang dikarenakan pabrik tersebut membuat perusahaan yang tidak sesuai standar lokasi.

Beberapa kasus yang peneliti temukan atas kerusakan lingkungan akibat kurang adanya pengendalian pada sector lingkungan atas beberapa kawasan industri di Kota Semarang sebagai berikut:

Lokasi Pencemaran :

- Warga Kelurahan Karanganyar, Kecamatan Tugu, Kota Semarang mengeluhkan limbah pabrik pengolahan baja yang mencemari lingkungan permukiman

- Lokasi pembuangan limbah dirasakan di desa Purwoyoso Kecamatan Ngaliyan Kota Semarang. Pabrik PT

\footnotetext{
${ }^{7}$ Suara Merdeka 15 Januari 2013 dengan judul PAD Kota Semarang Rp 2,4 triliun
} 
Marimas di Kawasan Industri Candi (KIC) Gatot Subroto Semarang.

Jenis limbah :

- Limbah PT. Ria Sarana berupa oli dari pabrik itu mengalir melalui selokan di samping rumahnya. "Debu-debu dari pengolahan juga sampai perumahan warga

- Limbah B3. Menurut PP No. 18 tahun 1999, yang dimaksud dengan limbah B3 adalah sisa suatu usaha dan atau kegiatan yang mengandung bahan berbahaya dan atau beracun yang karena sifat dan atau konsentrasinya dan atau jumlahnya, baik secara langsung maupun tidak langsung, dapat mencemarkan dan atau merusakan lingkungan hidup dan atau membahayakan lingkungan hidup, kesehatan, kelangsungan hidup manusia serta mahluk hidup lain.

Kedua kasus di atas setidaktidaknya dapat merepresentasikan kasus penyimpangan yang terjadi dalam praktik ketidakseimbangan pemerintah Kota Semarang dalam mempraktikkan konsep dan oreintasi pengembangan kawasan industri yang hanya diarahkan pada penerimaan daerah. Dalam hal pengendalian sektor lingkungan sebagai wujud dari pembangunan secara utuh masih mendapatkan perhatian yang kurang serius dengan diperlihatkan banyaknya kasus pada lahan industri.

Jika peneliti analisis dalam aspek yuridis, keberlakukan Peraturan Daerah Pemerintah Kota Semarang No 14 Tahun 2011 tentang Rencana Tata dan Ruang Wilayah memang cukup efektif sebagai ruang kontrol pemerintah Kota Semarang agar mampu mengendalikan pengembangan kawasan industri yang berwawasan kepentingan berkelanjutan. Peraturan Daerah Pemerintah Kota
Semarang No 14 Tahun 2011 tentang Rencana Tata dan Ruang Wilayah bukan hanya diarahkan/dihadirkan sebagai sarana peningkatan Pendapatan asli daerah tanpa batas.

Analisa Peraturan Daerah Pemerintah Kota Semarang No 14 Tahun 2011 tentang Rencana Tata dan Ruang Wilayah tersebut dapat peneliti uraikan dengan mengacu pada penjelasan Peraturan Pemerintah No 24 Tahun 2009 tentang Kawasan Industri yang menyatakan :

Pembangunan Industri merupakan salah satu pilar pembangunan perekonomian nasional, yang diarahkan dengan menerapkan prinsip-prinsip pembangunan Industri yang berkelanjutan yang didasarkan pada aspek pembangunan ekonomi, sosial, dan lingkungan hidup. Saat ini pembangunan Industri sedang dihadapkan pada persaingan global yang sangat berpengaruh terhadap perkembangan Industri nasional. Peningkatan daya saing Industri merupakan salah satu pilihan yang harus dilakukan agar produk Industri nasional mampu bersaing di dalam negeri maupun luar negeri.

Pembangunan Kawasan Industri merupakan sarana untuk mengembangkan Industri yang berwawasan lingkungan serta memberikan kemudahan dan daya tarik bagi investasi dengan pendekatan konsep efisiensi, tata ruang, dan lingkungan hidup. Aspek efisiensi merupakan suatu sasaran pokok pengembangan Kawasan Industri. Melalui pengembangan Kawasan Industri investor pengguna kaveling Industri (user) akan mendapatkan lokasi kegiatan Industri yang sudah tertata dengan baik, kemudahan pelayanan administrasi, ketersediaan infrastruktur yang lengkap, keamanan dan kepastian tempat usaha yang sesuai dengan 
Rencana Tata Ruang Wilayah (RTRW) kabupaten/kota.

Aspek tata ruang, pembangunan Kawasan Industri dapat mensinergikan perencanaan, prasarana dan sarana penunjang seperti penyediaan energi listrik, telekomunikasi, fasilitas jalan, dan lain sebagainya. Aspek lingkungan hidup, dengan pengembangan Kawasan Industri akan mendukung peningkatan kualitas lingkungan hidup di daerah secara menyeluruh. Kegiatan Industri pada suatu lokasi pengelolaan, akan lebih mudah menyediakan fasilitas pengolahan limbah dan juga pengendalian limbahnya.

Isi dan materi Peraturan Pemerintah No 24 Tahun 2009 tentang Kawasan Industri, jika di kaji berdasarkan asas-asas dalam Pasal 5 Undang-Undang Nomor 12 Tahun 2011 tentang Pembentukan Peraturan dalam perspektif peneliti tidak terdapat pertentangan/singkronisasi. Asas-asas dalam Pasal 5 adalah sebagai berikut :

a. "asas kejelasan tujuan" adalah bahwa setiap Pembentukan Peraturan Perundang-undangan harus mempunyai tujuan yang jelas yang hendak dicapai;

b. "asas kelembagaan atau pejabat pembentuk yang tepat" adalah bahwa setiap jenis Peraturan Perundangundangan harus dibuat oleh lembaga negara atau pejabat Pembentuk Peraturan Perundang-undangan yang berwenang. Peraturan Perundangundangan tersebut dapat dibatalkan atau batal demi hukum apabila dibuat oleh lembaga negara atau pejabat yang tidak berwenang;

c. "asas kesesuaian antara jenis, hierarki, dan materi muatan" adalah bahwa dalam Pembentukan Peraturan Perundang-undangan harus benarbenar memperhatikan materi muatan yang tepat sesuai dengan jenis dan hierarki Peraturan Perundangundangan;

d. "asas dapat dilaksanakan" adalah bahwa setiap Pembentukan Peraturan Perundang-undangan harus memperhitungkan efektivitas Peraturan Perundang-undangan tersebut di dalam masyarakat, baik secara filosofis, sosiologis, maupun yuridis;

e. "asas kedayagunaan dan kehasilgunaan" adalah bahwa setiap Peraturan Perundang-undangan dibuat karena memang benar-benar dibutuhkan dan bermanfaat dalam mengatur kehidupan bermasyarakat, berbangsa, dan bernegara;

f. "asas kejelasan rumusan" adalah bahwa setiap Peraturan Perundangundangan harus memenuhi persyaratan teknis penyusunan Peraturan Perundang-undangan, sistematika, pilihan kata atau istilah, serta bahasa hukum yang jelas dan mudah dimengerti sehingga tidak menimbulkan berbagai macam interpretasi dalam pelaksanaannya;

g. "asas keterbukaan" adalah bahwa dalam Pembentukan Peraturan Perundang-undangan mulai dari perencanaan, penyusunan, pembahasan, pengesahan atau penetapan, dan pengundangan bersifat transparan dan terbuka. Dengan demikian, seluruh lapisan masyarakat mempunyai kesempatan yang seluasluasnya untuk memberikan masukan dalam Pembentukan Peraturan Perundang-undangan.

Beberapa asas tersebut di atas tidak ada yang bertentangan dengan isi materi Peraturan Pemerintah No 24 Tahun 2009 tentang Kawasan Industri. Pada posisi lain, arah dan sudut pandang Peraturan Pemerintah No 24 tahun 2009 tentang Kawasan Industri juga sangat 
jelas bahwa aspek pembangunan berkelanjutan yaitu sinergi antara ekonomi, ekologi dan sosial menjadi dasar terbentunya kebijakan pengembangan kawasan industri. Dalam praktik yuridis jika kita tinjau dari konsep pembangunan berkelanjutan orientasi pemerintah Kota Semarang dalam pembuatan kebijakan legalisasi kawasan industri sudah sangat sesuai dalam menyeimbangkan antara faktor ekonomi, ekologi dan sosial.

Namun, dalam praktik aplikasi pengembangan kawasan industri atau aplikasi amanat perundang-Undangan yang berlaku, pemerintah nampaknya masih setengah hati. Dilema atas kurang maksimalnya kesimbangan antara orientasi pengembangan kawasan industri dalam upaya peningkatan pendapatan asli daerah dengan melihat kurang dijalankannya prinsip-prinsip pembangunan berkelanjutan.

Prinsip-prinsip pembangunan berkelanjutan yang kurang terakomodir dalam implementasi pengembangan kawasan industri tersebut sebagai berikut:

1. Keadilan (intergenerational equity);

2. Keadilan dalam satu generasi (intragenerational equity);

3. Prinsip pencegahan dini (precautionary principle);

4. Perlindungan keanekaragaman hayati (conversation of biological diversity); dan

5. Internalisasi biaya lingkungan (internalisation of environment cost and incentive mechanism).

Pencemaran lingkungan yang dimotori oleh perusahaan-perusahaan dikawasan industri di Kota Semarang, telah menjadi pembuktian bahwa orientasi pemerintah Kota Semarang belum maksimal dalam menjalankan prinsip pembangunan berkelanjutan dan lebih menonjolkan aspek penerimaan daerah. Seharusnya, pemerintah Kota Semarang dengan konsekwensi menjalankan pengembangan kawasan industri harus siap dengan konsekwensi adanya penyimpangan yang terjadi yang salah satunya dengan menindak perusahaan yang membuang limbah sembarangan.

Berangkat dari kenyataan tersebut, peneliti berpijak pada sebuah teori bahwa selalu ada bentuk konfigurasi di dalam hukum, dalam catatan pemikiran Satjipto Rahardjo mengatakan: baik faktor, peranan manusia, maupun masyarakat, ditampilkan kedepan, sehingga hukum lebih tampil sebagai medan pergulatan dan perjuangan manusia. Hukum dan bekerjanya hukum seyogyanya dilihat dalam konteks hukum itu sendiri. Hukum tidak ada untuk diri dan keperluannya sendiri, melainkan untuk manusia, khususnya kebahagiaan manusia. 8

Berdasarkan penjelasanpenjelasan tersebut di atas dapatlah ditarik suatu kesimpulan, bahwa masalah pokok daripada penegakan hukum sebenarnya terletak pada faktor-faktor yang mungkin mempengaruhinya. Faktor-faktor tersebut mempunyai arti yang netral, sehingga dampak positif atau negatifnya terletak pada isi faktorfaktor tersebut, antara lain:

a. faktor hukumnya sendiri, yang di dalam tulisan ini akan dibatasi pada undang-undang saja;

b. faktor penegak hukum, yaitu pihakpihak yang membetuk maupun menerapkan hukum;

8 Satjipto Rahardjo, 2007, Biarkan Hukum Mengalir (Catatan Kritis Tentang Pergulatan Manusia dan Hukum), Penerbit Buku Kompas, Jakarta, hlm. ix 
c. faktor sarana atau fasilitas yang mendukung penegakan hukum;

d. faktor masyarakat, yakni lingkungan di mana hukum tersebut berlaku atau diterapkan;

e. faktor kebudayaan, yakni sebagai hasil karya, cipta dan rasa yang didasarkan pada karsa manusia di dalam pergaulan hidup. ${ }^{9}$

Berdasarkan paparan teori di atas memang faktor penegak hukum/manusia sebagai pelaksana perundang-undangan sangat menentukan terwujudnya hukum yang dapat dijalankan dengan baik. Faktor penegak hukum, yaitu pihakpihak yang membentuk maupun menerapkan hukum jika memiliki cara berpikir yang jernih dan bersih untuk menjalankan amanat dari Peraturan Pemerintah No 24 tahun 2009 tentang Kawasan Industri yang tertuang secara teknis dalam Perda Kota Semarang, akan menjadi indikator suksesnya kebijaan pengembangan kawasan industri.

Dalam pembuatan kebijakan, kebijakan tidak hanya berfungsi menciptakan adanya keseimbangan diantara kepentingan-kepentingan yang berbeda (muddling through or balancing interests), tetapi harus berfungsi sebagai penilai (valuer). Artinya ia harus mampu menciptakan adanya nilai yang dapat disepakatri bersama yang didasarkan pada penilaian-penilaian rasional (rasional judgements). Ini dimaksudkan untuk mencapai hasil yang maksimal. Ketidakmampuan dalam mengartikulasikan dan menganalisa nilai-nilai (terutama nilai-nilai yang bertentangan) akan berarti tidak terwujudnya kepentingan masyarakat. Menyadari hal itu, maka system nilai mempunyai

\footnotetext{
${ }^{9}$ Soerjono Soekanto, 2002. Faktor-Faktor Yang Mempengaruhi Penegakan Hukum, Cetakan Keempat, PT. Raja Grafindo Persada, Jakarta, hlm. 5 .
}

kedudukan dan peranan yang strategis dalam perumusan kebijakan Negara ${ }^{10}$.

Nilai yang dimaksud dijabarkan oleh pemerintah yang dalam hal ini masuk kategori struktur hukum. Teori sistem hukum dari Lawrence $\mathrm{M}$. Friedman ${ }^{11}$ menyatakan bahwa sebagai suatu sistem hukum dari sistem kemasyarakatan, maka hukum mencakup tiga komponen yaitu:

1. Pertama-tama, sistem hukum mempunyai struktur. Sistem hukum terus berubah, namun bagian-bagian sistem itu berubah dalam kecepatan yang berbeda, dan setiap bagian berubah tidak secepat bagian tertentu lainnya. Ada pola jangka panjang yang berkesinambungan-aspek sistem yang berada di sini kemarin (atau bahkan pada abad yang terakhir) akan berada di situ dalam jangka panjang. Inilah struktur sistem hukum-kerangka atau rangkanya, bagian yang tetap bertahan, bagian yang memberi semacam bentuk dan batasan terhadap keseluruhan. Struktur sistem hukum terdiri dari unsur berikut ini : jumlah dan ukuran pengadilan, yurisdiksinya (yaitu, jenis perkara yang diperiksa, dan bagaimana serta mengapa), dan cara naik banding dari satu pengadilan ke pengadilan lain. Jelasnya struktur adalah semacam sayatan sistem hukum-semacam foto diam yang menghentikan gerak.

2. Aspek lain sistem hukum adalah substansinya. Yaitu aturan, norma, dan pola prilaku nyata manusia yang

\footnotetext{
${ }^{10}$ Irfan Islami, 2004, Prinsip-Prinsip Perumusan Kebijaksanaan Negara, Bumi Aksara, Jakarta, hlm 121

${ }^{11}$ Lawrence M. Friedman, 2001, American Law An Introduction Second Edition (Hukum Amerika Sebuah Pengantar) Penerjemah Wishnu Basuki, Penerbit PT. Tatanusa, Jakarta, hlm 7-9.
} 
berada dalam sistem itu. Substansi juga berarti "produk" yang dihasilkan oleh orang yang berada dalam sistem hukum itu - keputusan yang mereka keluarkan, aturan baru yang mereka susun. Penekannya di sini terletak pada hukum hukum yang hidup (Living law), bukan hanya pada aturan dalam kitab hukum (law books).

3. Komponen ketiga dari sistem hukum adalah budaya hukum. Yaitu sikap manusia terhadap hukum dan sistem hukum-kepercayaan, nilai, pemikiran, serta harapannya. Dengan kata lain budaya hukum adalah suasana pikiran sosial dan kekuatan sosial yang menentukan bagaimana hukum digunakan, dihindari atau disalah gunakan. Tanpa budaya hukum, sistem hukum itu sendiri tidak akan berdaya-seperti ikan yang mati terkapar di keranjang, bukan seperti ikan hidup yang berenang di lautnya.

Peran dari pemerintah sebagai struktur hukum dalam mewujudkan kawasan industri untuk mendongkrak kesejahteraan masyarakat selayaknya tidak diorientasikan sebagai bentuk dari kepentingan peningkatan pendapatan asli daerah saja. Faktor keberlanjutan pembangunan utamanya dalam bidang pengelolaan lingkungan harus menjadi pertimbangan penting bagi landasan aplikatif kebijakan yang dijalankan.

Paradigma dan tradisi pemerintah daerah mengukur kemajuan daerah dengan indikator angka-angka statistik Pendapat Asli Daerah tentunya harus dihapuskan. Nilai keberlanjutan pembangunan yang paling tidak terdapat dalam indikator konsep pembangunan berkelanjutan harus menjadi indikator bagimana pengembangan kawasan industri pada masa akan datang diarahkan. Diharapkan dimasa-masa yang akan datang, tidak ada istilah bahwa anak cucu kita sudah tidak mampu menjalankan pembangunan dengan baik, akibat warisan kerusakan pembangunan yang telah kita jalankan saat ini.

\section{KESIMPULAN}

Kota Semarang sebagai pusat kota di provinsi Jawa Tengah telah menjadi lokasi baru yang cukup representatif dalam menanamkan investasi. Hal inilah yang kemudian terbukti dengan semakin banyak dan berkembangnya jumlah industri di Kota Semarang. Data Disperindag Kota Semarang menyebut-kan jumlah total industri kecil, sedang dan besar di Kota Semarang pada 2013 sebanyak 3.589. Dari jumlah tersebut, sekitar 2.000-an berkategori industri sedang dan besar dengan nilai investasi di atas Rp 200 juta. Berdasarkan data nilai investasi inilah pemerintah Kota Semarang menggalakkan pengembangan kawasan industri yang utamanya diarahkan pada faktor peningkatan Penerimaan Asli Daerah.

Di Kota Semarang terdapat 9 (sembilan) kawasan Industri tersebut adalah kawasan industri Wijayakusuma, Kawasan Industri Terboyo, Kawasan Industri Lamicitra Nusantara, dan Kawasan Industri Bukit Semarang Baru, Lingkungan industri Kecil Bugangan Baru, Kawasan Industri Guna Mekar Tambak Aji, Kawasan Industri Candi, Kawasan Industri Tugu, dan Kawasan Industri Sinar Centra Cipta. Tingkat okupansi sembilan kawasan industri seluas 1.029 hektare di kota itu mencapai $75 \%$. Namun pada sisi lain persoalan yang kemudian mengemuka adalah masalah lingkungan hidup. 
Pada kawasan industri di Kota Semarang terdapat pencemaran yang secara sistematis sangat merugikan pembangunan yang akan dijalankan pada masa yang akan datang. Praktik penyimpangan pembangunan kawasan industri dari sektor lingkungan inilah yang menunjukkan bahwa pemerintah daerah Kota Semarang lebih menitikberatkan pada faktor pendapatan daerah yang seyogyanya dikaji ulang.

Di Kota Semarang, pemerintah daerah telah menerbitkan Peraturan Daerah Pemerintah Kota Semarang No 14 tahun 2011 tentang Rencana Tata dan Ruang Wilayah, yang isinya mengatur lokasi yang dijadikan sebagai kawasan industri. Regulasi yang dibuat tersebut telah berpijak pada Peraturan Pemerintah No 24 Tahun 2009 tentang Kawasan Industri.

Berdasarkan aspek yuridis, ketentuan Peraturan Daerah Pemerintah Kota Semarang No 14 tahun 2011 tentang Rencana Tata dan Ruang Wilayah sebagai acuan praktik pengembangan kawasan industri tidak menyalahi ketentuan yang ada. Ketentuan yang dimaksud salah satunya adalah dalam Undang-Undang Nomor 12 Tahun 2011 tentang Pembentukan Peraturan yaitu pasal 5 tentang asas-asas pembentukan peraturan perundangundangan. Namun dalam praktiknya, ketentuan dalam Peraturan Daerah Pemerintah Kota Semarang No 14 tahun 2011 tentang Rencana Tata dan Ruang Wilayah tidak dijalankan dengan baik. indikator tidak dijalankan dengan baik adalah terdapat pembiaran atas pembuangan limbah pada beberapa lokasi kawasan industri.

Selayaknya dengan pengembangan kawasan industri, pemerintah secara sadar menjadi dipermudah dalam melakukan pengontrolan apabila terjadi- nya penyimpangan. Namun jika pemerintah tidak serius dan hanya berorientasi keuntungan semata, maka akan dikhawatirkan menimbulkan problematika di kemudian hari yaitu persoalan dilema dan ketimpangan pembangunan yang utamanya diharapkan dapat dijalankan pada masa yang akan datang. Disinilah pentingnya menjalankan prinsip-prinsip pembangunan berkelanjutan dalam pengembangan kawasan industri yang tidak saja hanya dikembangkan pada arah meningkatnya pendapatan asli daerah dan terkuranginya pengangguran, akan tetapi juga melihat factor lingkungan sebagai indicator berhasilnya suatu wujud pembangunan secara nyata.

Saran yang dapat peneliti berikan berdasarkan hasil penelitian yang telah peneliti jalankan sebagai berikut :

1. Diharapkan pemerintah kota semarang lebih secara serius untuk melakukan pengawasan pada kawasan industri yang telah ada di Kota Semarang utamanya pada masalah lingkungan;

2. Pemerintah Kota Semarang harus membuat team independen yang bertugas untuk melakukan pengawasan secara simultan berkesinambungan dan sistematis terhadap pelaksanaan kegiatan industri yang ada pada kawasan industri;

3. Pemerintah Kota Semarang harus secara tegas melakukan penindakan kepada industri yang melakukan penyimpangan dan jika diperlukan mencabut izin menjalankan kegiatan industri sehingga nantinya menjadikan efek jera kepada perusahaanperusahaan lain yang dimungkiankan mereka akan melakukan penyimpangan. 


\section{DAFTAR PUSTAKA}

\section{Buku-Buku}

Irfan Islami, 2004, Prinsip-Prinsip Perumusan Kebijaksanaan Negara, Bumi Aksara, Jakarta

Lawrence M. Friedman, 2001, American Law An Introduction Second Edition (Hukum Amerika Sebuah Pengantar) Penerjemah Wishnu Basuki, Penerbit PT. Tatanusa, Jakarta

Lexi J. Moleong, 2007, Metodologi Penelitian Kualitatif, Rosda, Bandung

Ronny Hanitijo Soemitro, 1988, Metode Penelitian Hukum dan jurimetri, Ghalia Indonesia, Jakarta

Satjipto Rahardjo, 2007, Biarkan Hukum Mengalir (Catatan Kritis Tentang Pergulatan Manusia dan Hukum), Penerbit Buku Kompas, Jakarta

Soerjono Soekanto, 1981, Pengantar Penelitian Hukum, UI Press, Jakarta Soerjono Soekanto, 2002. Faktor-Faktor Yang Mempengaruhi Penegakan Hukum, Cetakan Keempat, PT. Raja Grafindo Persada, Jakarta

\section{Jurnal/Koran}

Suara Merdeka 15 Januari 2013 dengan judul PAD Kota Semarang Rp 2,4 triliun

\section{Internet}

Fazalaili Rahmawati A Dkk, Detail Engineering desain (ded) sistem Penyaluran air limbah dan instalasi pengolahan Air limbah kawasan industri bsb city, mijen Kota Semarang, diunduh dari situs yang beralamat
eprints.undip.ac.id/40954/1/JURNA L.docx

http://kabar24.bisnis.com/read/20140508/ 78/226142/kawasan-industri-kotaSemarang-hampir-penuh http://pelanggan.if-kom.com, Pemerintah Diminta Tindak Pencemaran Limbah Pabrik Baja, selasa 29 november 2011

Kontan.co.id, 7,24 juta orang Indonesia adalah pengangguran, diunduh pada tanggal 12 januari 2015 pada situs http://nasional.kontan.co.id/news/72 4-juta-orang-indonesia-adalahpengangguran

\section{Perundang-Undangan}

Undang-Undang Dasar Negara Republik Indonesia tahun 1945

Undang-Undang Nomor 32 Tahun 2004 tentang Pemerintahan Daerah yang telah disempurnakan dengan Undang-Undang No. 12 Tahun 2008 tentang Pemerintahan Daerah

Undang-undang No. 32 Tahun 2009 tentang Perlindungan dan Pengelolaan Lingkungan Hidup

Undang-Undang Republik Indonesia Nomor 3 Tahun 2014 Tentang Perindustrian

Peraturan Pemerintah Nomor 24 tahun 2009 tentang Kawasan Industri

Peraturan WaliKota Semarang nomor 35 tahun 2008 tentang penjabaran tugas dan fungsi dinas perindustrian dan perdagangan Kota Semarang

Peraturan Daerah Nomor 14 Tahun 2011 tentang RTRW Kota Semarang 2011-2031 